"Creating economic viability in rural South Africa through water resource management in subsistence farming"

\begin{tabular}{|c|c|c|}
\hline AUTHORS & $\begin{array}{l}\text { Bakre Olayemi } \\
\text { Dorasamy Nirmala }\end{array}$ & \\
\hline ARTICLE INFO & \multicolumn{2}{|c|}{$\begin{array}{l}\text { Bakre Olayemi and Dorasamy Nirmala (2016). Creating economic viability in } \\
\text { rural South Africa through water resource management in subsistence farming. } \\
\text { Environmental Economics, } 7(4), 68-77 . \text { doi:10.21511/ee.07(4).2016.07 }\end{array}$} \\
\hline DOI & \multicolumn{2}{|c|}{ http://dx.doi.org/10.21511/ee.07(4).2016.07 } \\
\hline RELEASED ON & \multicolumn{2}{|l|}{ Friday, 09 December 2016} \\
\hline JOURNAL & \multicolumn{2}{|l|}{ "Environmental Economics" } \\
\hline FOUNDER & \multicolumn{2}{|c|}{ LLC "Consulting Publishing Company "Business Perspectives" } \\
\hline \multirow[b]{2}{*}{ NUMBER OF REFERENCES } & & $\begin{array}{l}\text { ニ=: } \\
\text { =-z- }\end{array}$ \\
\hline & NUMBER OF FIGURES & NUMBER OF TABLES \\
\hline 0 & 0 & 0 \\
\hline
\end{tabular}

(C) The author(s) 2022. This publication is an open access article. 
Bakre Olayemi (South Africa), Dorasamy Nirmala (South Africa)

\title{
Creating economic viability in rural South Africa through water resource management in subsistence farming
}

\begin{abstract}
The purpose of this paper is to analyze the role water resources management can play in improving subsistence farming in rural South Africa, as well as reducing poverty. The study followed a mixed research approach where attributes of qualitative and quantitative methods were used. This paper indicates that due to water scarcity experienced amongst subsistence farmers in case study area, several farmers have opted out of farming. This has a negative consequence on food security and poverty among many subsistence farmers. The paper suggests the pathways for sustainable subsistence farming aimed at creating an economically viable rural community while addressing poverty through the implementation of an efficient water resources management practice. As highlighted in this paper, development is a gradual process, and water resources management can possibly be the first step in creating an economically viable community while alleviating poverty among subsistence farmers in water scarce rural areas of South Africa. Revamping the subsistence farming, as well as improving the standard of living amongst rural subsistence farmers requires a purposeful co-ordination and exchange of ideas between experienced agricultural extension workers, researchers in the field of context, policy makers, as well as other stakeholders. Such purposeful co-ordination should have an agenda of transforming the subsistence farming to a commercialized form of farming in the long term. The resultant effect will possibly result in an economically viable community; increase in household income, as well as food security, thereby reducing poverty.
\end{abstract}

Keywords: subsistence farming, rural development, water resource management, economic viability, poverty eradication, agricultural extension.

JEL Classification: Q12, N5.

\section{Introduction}

South Africa's rural areas are amongst the poorest in the world, as there is still a wide gap in terms of development with their urban neighbors (Koch, 1993, p. 28; Government Communication and Information System, 2013, pp. 2-4; Department of Rural Development, 2013, p. 13). An estimated 6.4 million South Africans fell below the national poverty line in 2010 (Schwabe, 2010, p. 58), most of whom reside in rural areas.

The majority of the rural dwellers in South Africa rely on subsistence farming, while others depend on government grants or family members living and working in urban areas to sustain a living. This income received is often insufficient to cater for their daily needs; hence, this resulted in a high percentage of rural community members of South Africa living below the poverty line (Allen and Brennan, 2004, p. 47 cited by Bakre, 2015, p. 2). Baiphethi and Jacobs (2009, p. 5) affirm that subsistence farming can play an integral role in the livelihoods amongst the rural poor, as it enhances food security.

In rural development literature, agriculture is considered as the best vehicle to reducing rural

(C) Bakre Olayemi, Dorasamy Nirmala, 2016.

Bakre Olayemi, Durban University of Technology, South Africa.

Dorasamy Nirmala, Professor, Durban University of Technology, South Africa. poverty; however, this development is stagnated by water scarcity which has adversely affected the Mtubatuba subsistence farming community. More so, subsistence farming could serve as an option to erratic and unreliable household income, especially when the main income-earner is unable to provide money for food purchases, as well as releasing cash for other household uses. This invariably reduces the over-reliance on cash to purchase food and, thus, the demand for cash in feeding the household (Baiphethi and Jacobs, 2009, p. 15). Subsistence farming often thrives in regions having sufficient water for agricultural purposes, but such is not the case in the community of Mtubatuba, as it is characterized by erratic rainfall and semi-arid soil. More so, evidence provided by Mr. Velaphi Myeza (Extension Officer to the Department of Agriculture, Environmental Affairs and Rural Development in Mtubatuba Municipality) reveals that the subsistence farmers of Mtubatuba over the last few years have had to farm under relatively harsh conditions in which rainfall is unpredictable and soil fertility is declining.

Water availability is on the decline, and forecasted to be worse with passage of time. Water shortages are likely to spread due to increasing demands from an unabated population growth, unsustainable withdrawal, development pressure on land and water, the prevalence and spread of invasive alien plant species, difficulty in finding new supplies, the changing climatic and precipitation patterns 
(Blignaut and Heerdeny, 2009, p. 1). Also many of the water resources are being polluted by industrial effluents, domestic and commercial sewage, acid mine drainage, agricultural run-off and litter. Taigbenu, Ncube and Boroto (2010, p. 2) are of the opinion that water crisis is due to the wasteful and unsustainable manner that water is being used and managed in some parts of the world.

In line with the above issues, the need of water resources management arises to maximize the limited water resources, and use in the most productive manner which could translate into a better standard living condition among rural subsistence farmers, hence, taking them out of the poverty cycle in the long run.

The purpose of this paper is to analyze the role water resources management can play in improving subsistence farming in rural South Africa, as well as reducing poverty to the barest minimum. It further aims to determine the effect of insufficient water supply on the agricultural sector in rural areas of South Africa.

It is important to identify and address the aforementioned challenges, as research has shown that a strong relationship exists between food insecurity, poverty and access to productive water and land. The living standards of poor smallholder farmers can be drastically improved if they are impacted with the skills and tools for managing water, even under rain-fed agriculture, so that their crops receive adequate water from the time of planting to that of harvest. In that way, crop failures are minimized, crop yields can be increased with attendant benefits of improved incomes and livelihood (Taigbenu et al., 2010, p. 5).

\section{Background of case study area}

This paper focuses on Mtubatuba Municipality situated on the coastline of North Eastern KwaZuluNatal. This area is one of the poorest farming rural areas in South Africa. The community is in need of development, as it lacks adequate access to basic services such as water, electricity, sanitation and tarred roads. The poor quality housing and lifestyle of residents are indicators of a poor socio-economic background. Subsistence farming is the dominant economic activity in the rural area of this Municipality. Mtubatuba has 19 wards comprising of an estimated 35,000 households and 180,000 people.

Mtubatuba is a water scarce settlement. The insufficient water supply has been a major hindrance to the growth and development of subsistence farming in this locality. At Mtubatuba, the river intake water treatment plant is designed to pump and purify 12 million litres per day, but is currently operating at capacity of 16 million litres per day, which is still insufficient to support the current level of development, let alone cope with the desperately needed residential, commercial, agricultural and industrial growth and development.

The Mfolozi River is the main source of water supply, whose water reduces tremendously during the winter period (April-August). Ironically, the Jozini Dam which is the largest dam in KwaZuluNatal and among the largest in South Africa is situated adjacent to Mtubatuba Municipality. This dam supplies water only to Zululand, and does not supply water to Umkanyakude, which is in great need of water (Mtubatuba Municipality is one among the 5 other Municipalities in Umkanyakude).

The agricultural produce is dependent on erratic rainfall. Most rainfall occurs in the summer months, which often lasts from November to March, with little or no rainfall falling in May to October. Due to the water scarcity during winter months, the Umkanyankude water services (water supplier to Mtubatuba Municipality), supplies water to residents for domestic purposes, which is often insufficient, as reported by some of the residents.

According to a senior official from the Department of Water Affairs (DWA), the illegal water connections to the main water supply often cause the disruption of water supply to the main users. Also mentioned was the adverse effect of the Tendelecoal Mining Pty Ltd has on the limited water resource, as this mining company contaminates the water resource, making it unsuitable for domestic and agricultural purposes.

The remaining parts of this paper are sequenced as follows: a discussion on subsistence farming among rural communities of South Africa. This is followed by the role of agricultural extension workers in subsistence farming. More so, the impediments to subsistence farming in the area of study are discussed. The proceeding section highlights the effect of poor, as well as the impact of an efficient water resources management on agriculture. Furthermore, the imperativeness of skilled and experienced agricultural extension workers was elaborated upon, while the final section provided practicable recommendations, as well as conclusion.

\section{Subsistence farming in rural South Africa}

2.1. Background. Subsistence farming is defined as "the production of sufficient food and fibre to satisfy the needs of the farming family". It was a common practice in the past, where large number of farmers 
produced only what they required. They collected fuel and building materials in their community, and played little part in the cash economy (Spedding 1979 cited in Wim Van Averbeke, 2008, p. 1).

According to Spedding (1979 cited in Wim Van Averbeke, 2008, p. 1), subsistence farmers produce mainly for household consumption and not for sale. However, Makeham and Malcolm (1986) are of the opinion that subsistence farmers sell some of their produce. They identified the production of sufficient food to feed the household as the primary objective of subsistence farming, while earning some cash income and accumulation of savings were secondary.

The agricultural sector of South Africa is considered to be dualistic in nature, as it comprises the capitalized commercial sector, on the one hand, and the fluctuating subsistence sector, on the other hand (Vink and Kirsten, 2003; May and Carter, 2009). Many leading South African agricultural economists describe this sector as consisting of a developed part, on the one hand, and a developing one, on the other hand. The commercial farming is considered to be developed, market-oriented and on a large scale, while the subsistence farming is developing, and on a small scale. The market-oriented part is dominated by White farmers, while the African farmers dominate the subsistence part. There is a general concession by researchers that this divide is a legacy of racially discriminatory policies of the apartheid era which stunted the natural agricultural development processes among the black farmers (Lahiff, 2000; Ortmann and Machete, 2003 cited in Wim Van Averbeke, 2008, p. 9).

2.2. Role of subsistence farming in rural South Africa. As earlier stated, subsistence farming is the mainsource of livelihood in the area of study. Majority of the residence are uneducated and lack required skills to compete for the limited job opportunities in Mtubatuba Municipality. Most of the households farm mainly for food security. Some of the residents of this community claim food produced through subsistence farming are a form of income. Also, they consider farming to be a part of their lifestyle. Households often make great attempts during the raining summer period to store food. This is to serve as backup in case they do not have sufficient income during the dry winter period to buy food items. However, storing sufficient food for dry winter months have been challenging, as they are unable to produce sufficient food during the rainy summer months; more so, the lack of storage facilities for food crops has been an undermining concern.

According to Baiphethi and Jacobs (2009, p. 7), households access food mainly through three sources:

- food purchases in the market place;

- subsistence production; and

- transfer from public programs or other households.

A random survey among the rural community of Mtubatuba reveals that very few food items are purchased from the market place, while more than half of foods consumed are produced from their farms. Some also claim they seldom receive few items through neighbors.

Hendriks (2003, p. 39) argues that subsistence production provides two distinct nutritional benefits. It serves as fresh food consumption for the household, and also it's a means of saving income that might have been spent on even more nutritious foods the farmers might not be in a position to produce. He further states that home consumption increases the availability of fresh vegetables and opportunity to increase micronutrient intake. The income saved from producing food by household seems to have more positive contribution on the nutritional status of residents of a rural community. Income saved could be subsequently used to purchase energy dense foods such as fats, oil and meat.

In a survey conducted amongst the rural households of KwaZulu-Natal (which comprises Mtubatuba Municipality), in order to discern the relationship between the incidence of stunting among children and the agricultural practices of their households, researchers come to the conclusion that "agricultural activities make a positive contribution to household nutrition, which suggests that designing effective programs for improving agricultural productivity in the less-developed areas of South Africa could have a potentially positive impact on household and child nutritional status" (Kirsten et al., 1998, p. 586).

Subsistence farming contributes economical to this deprived community, as without this mode of farming, many amongst the population are likely to be unemployed. Considering the multifaceted role subsistence farming plays on food security and earlier highlighted benefits in rural South Africa, more attention should be provided by governments at grassroots' levels. 
This agendum could be facilitated by experienced and self-mobilized agricultural extension workers.

2.3. Role of agricultural extension workers in subsistence farming. A significant proportion of subsistence farmers in the Mtubatuba community often farm in their locality and do not necessarily interact with their counterparts in other provinces or internationally. Hence, they rely on governmental departments and agricultural extension workers for information and support. This reliance on extension workers by subsistence farmers is not only confined to information giving; as they also serve as intermediaries between non-governmental organizations, governmental bodies and donors. Studies conducted by Rahman (2016, pp. 32-35), Babu, Joshi, Glendenning, Asenso-Okyere and Sulaiman (2013, pp. 159-161), and Karamagi and Nakirya (2009, pp. 59-62) do allude to the claim that experienced subsistence farmers in Bangladesh, India and Ugandahave significantly contributed to growth of subsistence farming in their respective countries. Sajesh and Suresh (2016, pp. 7-9), as well as Kaegi (2015, pp. 13-19) further mentions that the influence of agricultural extension workers in India has significantly mitigated the drought concern and has also lessened the concern of food insecurity.

Hence, these reveal that agricultural extension aforecited narratives worker's have been playing a pivotal role in the development of subsistence farming in their respective regions. However, such impact by agricultural extension workers of South Africa has not been as noticeable as those of the aforementioned countries (van Nieker, Stroebel, van Rooyen, Whitfield and Swanepoel, 2009, pp. 6669). Reiterating the fact that a surmountable percentage of community members of the Mtubatuba, alongside other rural communities of South Africa, are involved in subsistence farming (Calzadilla, Zhu, Rehdanz, Tol and Ringler, 2013, pp. 154-159) justifies the necessity to develop this mode of farming. Such development could be fostered through an efficient water resource management orchestrated by skilled and experienced agricultural extension workers.

\section{Definition of problems}

3.1. Constrains to the development of subsistence farming in rural South Africa. As pointed out earlier in this paper, subsistence farming has been shown to be important for rural household food security. The productivity is, however, quite low and in some cases, it has been a discouraging factor leading to abandonment of agricultural production by rural households (Baiphethi and Jacobs, 2009, pp. 18). A stumbling block to the growth of subsistence farming in the case study area is the erratic rainfall which is the only source of water supply to crops. The soil fertility is fast declining, as the area is classified as a semi-arid region. The poor soil fertility often affects crop yield to an unbearable extent, as reported by one of the farmers in the locality.

An uncontrollably natural challenge faced by the agricultural sector is that, with the global population increases, this sector will be expected to increase its food production by feeding more humans with the diminishing water resource, to achieve national food security. It implies more food production with less amounts of water. This is, no doubt, a challenge to future generations (Taigbenu, et al., 2010, p. 3).

According to Mati (2007, p. 4), the most vulnerable people to climate-related disasters are the poor smallholder farmers (subsistence farmers). This is as a result of their inability to access cutting edge knowledge, afford inputs or utilize appropriate technologies that can mitigate natural disadvantages such as the negative effect of the climate change. However, this cutting edge knowledge could be acquired through the deployment of seasoned agricultural extension workers.

South Africa's climate, as well as the relative scarcity of water experienced in most farm lands and the low potential of arable land available to subsistence farmers often results in risky crop production (Ortmann and Machethe, 2003 cited by Aliber and Hart, 2010, p. 436). This further exacerbates the level of poverty among rural subsistence farmers, as they are forced to purchase costly inputs which ties down their little capital.

Due to the water scarcity, farmers in study area consider it risky to attempt to produce most of the exotic crops. This, however, stagnates the growth of subsistence farming, as farmers are dissuaded from planting some crops. Whereof, they are limited to specific crops which will not require much water for its yield. Consequently, the subsistent farmers engage in more intensive and diverse practices and crops in order to reduce risk while ensuring food security in the household (Aliber and Hart, 2010, p. 436).

Another considerable act constraining the development of subsistence farming is the ruralurban migration. As many rural dwellers migrate to cities in search of better opportunities, this invariable reduces the labor force available for farming in rural places. Goldsmith, Gunjal and 
Ndarishikanye (2003, p. 5) assert that "economic theory and empirical research have shown that the foundation of rural-urban migration is the excess of the urban wage over the rural wage".

In instances where farmers had access to crop land, they could not maximize land usage, as they lacked the implements and other resources to cultivate. In a study in Eastern Cape, it was observed that even when resources were pooled amongst five rural households, required equipment were still not met (Fraser et al., 2003 cited by Aliber and Hart, 2010, p. 436). The lack of resources is typical amongst many subsistence farmers in rural South Africa.

According to Baiphethi and Jacobs (2009, p. 18) household assets are considered as major determinants to subsistence farmers' ability in agricultural production and to secure a livelihood through subsistence farming. They further state that the lack of assets for agricultural usage is predominant in Sub-Saharan Africa, as evidenced by unviable small and falling farm sizes and poorquality land. In addition, they assert that the poor health services and education further limit development and growth of farming and access to other livelihood options.

In particular, there is a need for alternative approaches to the growth and development of subsistence farming in rural South Africa. A way out of this challenge suggested by author is through the aid of an efficient water resource management strategy which can be initiated, sustained and developed by the deployment of experienced and learned agricultural extension workers.

\section{Procedure}

The study followed a mixed research approach, where both elements of the quantitative (questionnaires) and qualitative (interviews) approaches were used in gathering pertinent information regarding subsistence farming, poverty and water resource management. The researcher involved a total of 50 subsistence farmers in the Ward 19 area of Mtubatuba Municipality of KwaZulu-Natal. More so, interviews were conducted amongst senior staff members from the Mtubatuba Municipality, Department of Agriculture, Environmental Affairs and Rural Development in Mtubatuba, as well as technicians from the Umkanyakude water service providers whom are responsible for the water provision in Mtubatuba Municipality. The information obtained was used for triangulation purposes.

\section{Water resources management}

5.1. Effect of poor water resources management. Huge gaps still exist between water resources management approach and how water resources planning is been performed and what needs to be done (Bhatti, Koike and Nasu, 2012, p. 4). Bhatti et al. (2012) further state that the present water-use projection indicates clearly that by year 2025 , water demand will exceed supply under a business-asusual scenario. They are of the view that climate variations and changes, coupled with low water storage capacity are likely to aggravate this challenge. They conclude by recommending a sustainable management, by developing, allocating and utilizing water resources efficiently. Sustainable management of water resources is, therefore, a process element of sustainable human development and can address poverty and proffer a better standard of living, while opposite of this could result in poverty stricken conditions of individuals, particularly amongst rural subsistence farmers, farming in water scarce regions.

Poor water resource management will have a negative effect on the future of a country, especially on the agricultural sector which is responsible for above 70 percent of water usage in most of SubSaharan countries, which includes South Africa (Taigbenu, Ncube and Boroto, 2010, p. 4). Reason being that the agricultural sector will be expected to increase its food production with a reduced quantity of water. This is a challenge for generations to come (Taigbenu, et al. 2010, p. 3). As argued by Bhatti et al. (2012, p. 4), Pakistan is a country battling with water crisis not because of physical scarcities of water resources, but due to poor water resources management. For several decades, lack of knowledge, experience, technology and coordination among different institutions has been a major challenge for the water sector of Pakistan. As suggested by Bhatti et al. (2012, p. 1), an "empirical evidence shows that better management coupled with effective policy, intensified political will, appropriate investments, awareness, climatic change adoption and institutional strengthening are promising pathways for sustainable water resources management". The consequence of water mismanagement in Pakistan has resulted in food insecurity. To avoid a replication of this situation in South Africa, water resource management requires adequate attention.

5.2. Role of water resources management. Some among the Municipalities in South Africa do not have sufficient funds to finance irrigation projects for rural farmers. This has resulted in farmers applying traditional water conservative techniques 
to sustain their crops during the drought periods. This water conservative technique is passed down from generation to generation. However, in recent times, due to poor rainfall in Mtubatuba Municipality along with the declining soil fertility, subsistence farmers are unable to sustain their crop yields through the traditional conservative techniques used few years back. Bearing this in mind, a more technological advanced water resource management practice is required at area under study. Three vital questions, then, arise:

- What steps have been taken?

- What needs to be done?

- And, lastly, how can water resources management help to improve subsistence farming thereby reducing the level of poverty?

In answering the above questions, steps have been taken to sustain crop production during drought by the subsistence farmers, as well as the Department of Agriculture in Mtubatuba Municipality. As observed by the researcher, the invasive alien plants which compete with crops for water consumption have mostly been weeded to allow crops access to more water. In addition, the Department has provided some subsistence farmers with beddings, which reduce the impact of sunlight on crops thereby conserving water. This, however, is not sufficient to sustain crops and have a good harvest. What will salvage the situation is the training of subsistence farmers by agricultural extension workers on how to use some advanced water conservative techniques, as well as monitoring the process at specified intervals.

Considering the nature of soil type, rainfall pattern and crops grown in case study area, the following (three) water conservative methods are recommended, as they are affordable, easily created and could be maintained:

1. Bucket drip kits (drum kits).

2. Compost manure.

3. Contour stone bunds.

The abovementioned (three) water conservative techniques are explained below:

5.2.1. Bucket drip kits (drum kits). A bucket drip kit consists of two drip lines, each 15-30 meters in length having emitters spaced 0.1 to 0.3 meters apart. This also comes with a 20 litre bucket which serves as water storage. The impurities which may clog the drip nozzles during operation are connected to each of the drip lines to filter the impurities. The bucket drip kit is supported by a stand, with the base of the bucket at about one meter above the soil surface. To irrigate an estimated amount of 100-200 plants daily, the drip kit requires about 40-80 litres of water. This water conservative technique is common in countries such as Lesotho, Kenya, Tanzania, Zambia, and Zimbabwe, and has been used to cultivate high value vegetables such as spinach and tomatoes, and the yields were of good value (Sijali and Okumu, 2002; Sijali, 2001; Ngigi, 2003; SWMRG, 2005; IWMI, 2005 cited in Mati, 2007, p. 8).

5.2.2. Compost manure. This is a process whereby farmers transform organic materials such as farmyard manure and plant remains into humus. To make compost manure, the following steps are taken:

- Creating a foundation on which ashes are spread to prevent termites attack.

- Several layers of green vegetation such as "Lantana camara" and the topsoil are placed layer by layer.

- Wetting the heap with a non-chlorinated water.

- Heap is covered with soil.

- A stick is, then, driven into the heap to act as a thermometer.

- The heap is, then, turned after an estimated period of 3 weeks.

- And, lastly, the heap is once again wetted and ready for use within 6 weeks.

This method is fast gaining importance among subsistence farmers of Sub-Saharan Africa, which have similar soil type to that of South Africa. The yields over the years using the above mentioned method has been impressive (Sanchez et al., 1997; Njoroge, 1994; Kibwana, 2000; Critchley et al., 1999; Reij and Waters-Bayer, 2001 cited in Mati, 2007, p. 10).

5.2.3. Contour stone bunds. The last technique is suggested by the researcher due to the topography of the case study area. Mtubatuba farm lands are often characterized by slopes. During rainfall, most of the rain water flows at a fast speed retaining little amounts of water for crops. This conservation technique is prepared by arranging stones across a slope over a contour in order to produce a barrier. The crop is planted immediately ahead of the stone bund. The upper end of the terrace is set free to enable a catchment. These bunds are permeable, which causes the slow movement of water flow. It bunds filter the water flow, and thereafter spread over the farming land. This practice enhances water infiltration as well as reduction of soil erosion. As suggested by Mati (2007, p. 12), "stone bunds are especially safer to use since they form a porous barrier, which slows down runoff, and is unlikely to 
fail in case of extreme flooding" (Critchley and Siegert, 1991; Hilhorst and Muchena, 2000; Duveskog, 2001 cited in Mati, 2007, p. 12). Implementation of these strategies is capable of improving crop yield thereby reducing level of poverty in the long run.

\subsection{Imperativeness of skilled and experienced agricultural extension workers. Extensive studies} have been conducted on water resources management techniques, as well as water conservative techniques for agricultural purposes (Wilk and Jonsson, 2013; Patil, Sawant, Deshmukh, 2012). These extensive studies have bought about insightful and profound findings (Water Technology and Environment Control Exhibition and Conference (WATEC), 2014, pp. 3-8). Countries such as Israel and India have made significant advancement in water conservative techniques for agricultural purposes (Sajesh and Suresh, 2016, pp. 7-9; Knafo, 2015, pp. 2-3). These cutting edge advancements have been utilized to drive development in agriculture among different farming regions of Israel (Schacht, Chen, Tarchitzky, Marschner, 2016, pp. 460-464). These cutting edge advancements have been mainly driven by researchers, engineers and agricultural extension workers. However, many of the discoveries and findings on water conservation techniques developed in these regions have not been shared with other farmers who need these techniques. This view is amplified by Global Forum on Agricultural Research (GFAR 2008, pp. 3-5) as well as Karamagi and Nakirya, 2009, pp. 59-63) who affirm that several approaches have been developed, however, there is poor dissemination, or inadequate flow, or exchange of ideas. More so, it has been empirical proven that many of the cutting edge water conservative techniques in India are either spear headed or initiated by experienced agricultural extension workers (Sajesh and Suresh, 2016, pp. 7-9; (Kaegi, 2015, pp. 13-19). However, due to lack of skill amongst some of agricultural extension workers of South Africa, their level of contribution to the water conservation discussion had been minimal, thus such workers have not being able to contribute as much as their counterparts in countries such as Bangladesh, India or Israel. Highly skilled and experienced agricultural extension workers in Bangladesh have been partly given the credit for been able to produce times-three of what was produced three decades ago (Rahman, 2015, pp. 34-37). No doubt, highly skilled extension workers in South Africa could also produce a replica of what was achieved in Bangladesh; unfortunately, the sector faces a shortage of experienced and skilled agricultural extension workers (Mmbengw,
Gundidza, Groenewald and Van Schalkwyk, 2009, p.10). To bridge this gap, the imperativeness of regular training and workshops on water conservative techniques, as well as exchange of ideas between South African agricultural extension workers and their counterparts in other countries cannot be overemphasized.

\section{Summary}

As noted by Taigbenu et al. (2010, p. 3), the South African Water Act of 1998 promoted sustainable and efficient allocation of water resources within the groundwork of water resources management in enhancing the social-economic growth and development of the nation. The question been asked is what effect has this Act and various other similar Acts had at the grassroots' level? The current situation points out that the present Act and other similar ones and policies are relatively ineffective, as the same water challenges experienced by farmers of Mtubatuba decades ago are still ongoing.

In view of the various challenges facing the agricultural sector in rural South Africa, which includes, water scarcity, increasing loss of soil, rising input cost and dependence on external factors which the farmer has no control over (such as the oil price and exchange rate), high murder rate and increasing tenure insecurity (World Wildlife Fund, 2011, p. 5), the South African government has put in place measures to address these challenges. It has entrenched constitutional commitments to protecting the environment and for sustainable agricultural development. This is reflected in Section 24 of the Bill of Rights, which "provides everyone with the right' to an environment that is not harmful to their health or well-being". More also, in order to improve and regulate various aspects of agriculture, the South African government has initiated initiatives such as the White Paper on Agriculture, 1995; Discussion Paper on Agricultural Policy, 1998; Restitution of Land Rights Act, 22 of 1994; Transformation of Certain Rural Areas Act, 94 and Abolition of Racially-based Land Measures Act, 108 of 1991.

Despite the efforts made by the government to revamp the agricultural sector, the impact has not been felt by the subsistence farmers of Mtubatuba, as the farmers still farm in harsh conditions resulting in poor yields of farm produce. Empirical studies reveal that the government policies have not had a significance positive influence on subsistence farmers at the grassroots.

This points out to the fact that only government alone will not be able to handle this decaying sector. This view is buttressed by Masters et al. (1998) 
cited by Jayne, Mather and Mghenyi (2010, p. 10) when they state that "African economies would have been poorer, government finances would be in worse shape, food imports bills would be higher and more African countries will suffer from food security", if not for the great investments made on agriculture sector. This indicates that more investments need to be carried out through extensive research in the field of study. However, the findings and recommendations of these researches should be implemented on the farms, progress monitored, as well as regular feedbacks.

\section{Recommendation}

The suggested pathways to achieving a sustainable subsistence farming thereby reducing poverty are:

1) firstly, subsistence farmers should focus more on crops with low water demand such as beans. Crops with high water demand could as well be planted, as most of such crops contain high amounts of nutrients, but only during summer periods where there are better rainfalls. Strategies should be devised to replace crops which consume high amounts of water and low market crops with crops having high market value and low water demand. This strategy will have an inverse effect on food security, as well as generating income for the farmers.

2) secondly, skilled and experienced agricultural extension workers should work hand in hand with subsistence farmers, with the intent of training these farmers on water resources management techniques as a means to obtaining the best of crop yield even during periods of low rainfall. A periodic training will develop farmers' skills. These will result in farmers being more enlightened and exposed, and such knowledge could be transferred and improved from generation to generation.

3) thirdly, interactive participatory sessions among agricultural extension workers, subsistence farmers of Mtubatuba, governmental officers, donors and other stakeholders should be conducted regularly to identify issues, while strategizing practicable solutions.

4) fourthly, the deployed agricultural extension workers to rural communities should learn from their counterparts in countries such as Bangladesh, Israel and India as a means to replicating the cutting edge water conservative techniques adopted by subsistence farmers of these countries.

5) and, lastly, an awareness campaign on effective water usage should be embarked on. Empirical study reveals that some of the issues associated with management of water resources are as a result of poor understanding of water conservation techniques, as well as illiteracy amongst rural farmers. A door to door awareness campaign should be made by the Department of Agriculture in the Mtubatuba Municipality to sensitize farmers.

\section{Conclusion}

This study discusses the pathways for sustainable subsistence farming and poverty eradication through the implementation of an efficient water resources management practice. As highlighted in the study, development is a gradual process, and water resources management can possibly be the first step in elevating poverty among subsistence farmers in water scarce rural areas of South Africa.

Revamping the subsistence farming, as well as improving the standard of living amongst rural subsistence farmers requires a purposeful coordination and exchange of ideas between agricultural extension workers, researchers in the field of context, policy makers as well as stakeholders. Such purposeful co-ordination should have an agenda of transforming the subsistence farming to a commercialized form of farming in the long term. The resultant effect of this will be an increase in household income, as well as food security, thereby reducing poverty.

\section{References}

1. Aliber, M. and Hart, T. (2010). Should subsistence agriculture be supported as a strategy to address rural food insecurity? [online]. Available at: http://ageconsearch.umn.edu/bitstream $\quad$ 58215/2/5.\%20Aliber\%20\&\%20 Hart.pdf. Accessed on 7 July 2014.

2. Averbeke, V. (2008). Best management practices for small-scale subsistence farming on selected irrigation schemes and surrounding areas through participatory adaptive research in Limpopo province [online]. Available at: http://www.google.co.za/?gws_rd=cr\#bav=on.2,or.r_qf.\&fp=54d4d87d96ae6264\&q=Best+management+practi es +for+smallscale+subsistence. Accessed on 27 June 2014.

3. Babu, S., Joshi, P.K., Glendenning, C., Asenso-Okyere, K. and Sulaiman, R. (2013). The state of agricultural extension reforms in India: strategic priorities and policy options, Agricultural Economics Research Review, 26(2), pp. 159-172. Available at: http://ageconsearch.http://ageconsearch.umn.edu/bitstream/162155/2/2-SC-Babu.pdf. Accessed 11 January 2016 
4. Bakre, R.O. (2015). Water resource management for subsistence farming in ward 19 of kwaZulu-Natal [online]. M. Tech, Durban University of Technology. Available at: http://ir.dut.ac.za/bitstream /handle/10321/1305/ BAKRE_2015.pdf?sequence=1\&isAllowed=y. Accessed on 14 January 2016.

5. Baiphethi, M. and Jacobs, P. (2009). The contribution of subsistence farming to food security in South Africa [online]. Available at: http://ageconsearch.umn.edu/bitstream/58216/2/6.\%20Baiphethi\%20\&\%20Jacobs.pdf. Accessed on 27 July 2014.

6. Bhatti, A. Koike, T. and Nasu, S. (2012). Water resources management: pathways for sustainable economic growth and poverty eradication [online]. Available at: http://management.koch-itech.ac.jp/ssms_papers/sms125687_fd05c295e09d9310bc02c5ae26225212.pdf. Accessed on 15 July 2014.

7. Blignaut, J.N. (2007a). Is-water-shedding-next [online]. Available at: http://www.econrsa.org/papers/ wpapers/wp141.pdf. Accessed on 6 August 2014.

8. Blignaut, J.N. (2007b). Determining a charge for the clearing of invasive alien plant species (IAPs) to augment water supply in South Africa [online]. Available at: http://www.absa-wildlifeconference.co.za/ attachments/article/69/Determining. Accessed on 6 August 2014.

9. Calzadilla, A., Zhu, T., Rehdanz, K., Tol, R., Andringler, C. (2013). Economywide impacts of climate change on agriculture in Sub-Saharan Africa, Ecological Economics, Elsevier, 93(C), pp. 150-165.

10. Goldsmith, Gunjal, K and Ndarishikanye, B. (2003). Rural-urban migration and agricultural productivity: The case of Senegal [online]. Available at: http://www.rural21.com/uploads/media/R21_Migration_and_small_urbanisation _0209.pdf. Accessed on 21 June 2014.

11. Government communication and information system. (2013). Strategic Plan for the five year period [online]. Available at: http://www.gov.za/sites/www.gov.za/files/gcis_stratplan_12-17.pdf. Accessed on 19 November 2015.

12. Jayne, T.S., Mather, D,. Mghenyi, E. (2010). Principal challenges confronting smallholder agriculture in subSaharan Africa [online]. Available at: http://www.sciencedirect.com/science/article/B6VC6-50J9W0F4/2/e8fdfd56c5f7b526a8ecd6732f1c5e45. Accessed on 4 July 2014).

13. Kaegi, S. (2015). The experiences of India's agricultural extension system in reaching a large number of farmers with rural advisory services [online]. Available at: https://www.shareweb.ch/site/Agriculture-and-FoodSecurity/focusareas/Documents/ras_capex_india.pdf. Accessed on 8 February 2016).

14. Karamagi, E. and Nakirya, M. (2009). Tools for enhancing knowledge-sharing in agriculture: improvingrural livelihoods in Uganda [online]. Available at: http://pubs.iied.org/pdfs/G02841.pdf. Accessed on 17 March 2016.

15. Knafo, S. (2015). Selling the Desert's Water-Conservation Lessons to the Rest of the World [online]. Available at: http://www.theatlantic.com/business /archive/2015/05 /netafim-israel-water-conservation-irrigation-desert/393722. Accessed on 11 February 2016.

16. Mati, B. (2007). 100 ways to manage water for smallholder agriculture in eastern and southern Africa [Online] Available at: http://www.asareca.org/swmnet/downloads/1179993482SWMnet\%20Working\%20Paper\%2013\% 20100\%20Ways\%20of\%20AWM\%20in\%20ESA.pdf .Accessed on 2 July 2014.

17. Mmbengwa, V.M., Gundidza, M., Groenewald, J.A. and Van Schalkwyk, H.D. (2009). Factors affecting extension workers in their rendering of effective service to pre and post-settled farmers ingovernment initiated and supported farming small, micro and medium enterprises, S.Afr. Tydskr. Landbouvoorl./S. Afr. J. Agric. Ext., 38, pp. 1-14.

18. Patil. P.N., Sawant. D.V., Deshmukh, R.N. (2012). Physico-chemical parameters for testing of water - A review, International Journal of Environmental Sciences, 3(3) [online]. Available at: http://www.ipublishing.co.in/ijesarticles/twelve/articles/volthree/EIJES31120.pdf. Accessed on 22 March 2016.

19. Rahman, M. (2016). Back to Village? Women and vocational education for rural development. Rural Development Conference, Thailand, March 13-15, 2016. Belgrade: Tomorrow People Organization.

20. Sajesh, V.K. and Suresh, A. (2016). Public-Sector Agricultural Extension in India: A Note, The Journal of the Foundation for Agrarian Studies, 6(1). Available at: http://www.ras .org.in/public_sector_agricultural_extension_in_india. Accessed on 11 February 2016.

21. Schacht, K., Chen, Y., Tarchitzky, J. and Marschner, B. (2016). The Use of Treated Wastewater for Irrigation as a Component of Integrated Water Resources Management: Reducing Environmental Implications on Soil and Groundwater by Evaluating Site-Specific Soil Sensitivities. In: Borchardt, D., Bogardi, J., Ibisch, R. (ed). Integrated Water ResourcesManagement: Concept, Research and Implementation. $1^{\text {st }}$ ed. Switzerland: Springer International Publishing, pp. 459-470. [online]. Available at: http://link.springer.com/chapter/10.1007\%2F978-3319-25071-7_18. Accessed on 11 April 2016.

22. Schreiner, B. and Van Koppen. B. (2002). Catchment management agencies for poverty eradication in South Africa, Physics and Chemistry of the Earth, 27, pp. 969-976.

23. Schwabe, C. (2010). Monitoring the changing face of South Africa's poverty [online]. Available at: http://www.eepublishers.co.za/images/upload/positionit_2012/changing-face_visu_june12.pdf. Accessed on 23 May 2014.

24. Snellen, W.B. and Schrevel, A. (2004). Integrated water resource management: for sustainable use of water, 50 years of international experience with the concept of integrated water management [online]. Available at: http://www.fao.org/ag/wfe2005/docs/IWRM_Background.pdf. Accessed on 18 June 2014.

25. Statistics South Africa, community survey. (2007). [online] Available at: statssa.gov.za. Accessed on 7 July 2014. 
26. Taigbenu, A.E., Ncub, E.M. and Boroto, R.J. (2010). Water resources management in agriculture: convergence of needs and opportunities [online]. Available at: http://www.waternetonline.ihe.nl/challengeprogram/ NP02\%20Taigbenu\%20res\%20man\%20agric.pdf. Accessed on 10 July 2014.

27. Van Niekerk, J.A., Stroebel, A., Van Rooyen, C.J., Whitfield, K.P. and Swanepoel, F.J.C. Towards designing a new agricultural extension service for the Eastern Cape province: a perception analysis, S.Afr. Tydskr. Landbouvoorl./S. Afr. J. Agric. Ext., 38, pp. 65-76.

28. Water technology and environment control exhibition and conference (watec). (2014). Watec Peru 2014 Brochure [online]. Available at: http://www.environmental-expert.com/downloads/watec-peru-2014-brochure-440598. Accessed on 13 February 2016.

29. Wegerich, K. (2001). Natural drought or human made water scarcity in Uzbekistan? [online]. Available at: http://preventionweb.net/files/1776_VL102309.pdf. Accessed on 6 August 2014.

30. Wilk, J. and Jonsson, A. (2013). From water poverty to water prosperity - A more participatory approach to studying local water resources management, 27(1), pp. 695-713 [online]. Available at: www.divaportal.org/../FULLTEXT01.pdf. Accessed on 21June 2014.

31. World cup legacy report. (2010). South Africa: a water scarce country. South Africa: Department of Environmental Affairs [online]. Available at: https://www.environment.gov.za/sites/default/files/docs/water.pdf. Accessed on 29 July 2014. 